\title{
Decline of Ethics and Moral Values in Present Scenario - An Analysis
}

\author{
Roshan Parihar ${ }^{1 *}$, Poonam Parihar ${ }^{2}$ and Devendra Jeet Sharma ${ }^{1}$ \\ ${ }^{1}$ Department of Genetics and Plant Breeding, Barrister Thakur Chhedilal College of \\ Agriculture and Research Station, Sarkanda, Bilaspur, Chhattisgarh-495001, India \\ (Indira Gandhi Krishi Vishwavidyalaya, Raipur, Chhattisharh) \\ ${ }^{2}$ Department of Economics, Pundit Sunderlal Sharma (Open) University, Birkona, Bilaspur, \\ Chhattisgarh-495001, India \\ *Corresponding author
}

\begin{tabular}{|l|}
\hline K e y w o r d s \\
$\begin{array}{l}\text { Indian education } \\
\text { system, Ethical } \\
\text { decline, Moral } \\
\text { education, Moral } \\
\text { values, Ethics }\end{array}$ \\
\hline Article Info \\
\hline $\begin{array}{l}\text { Accepted: } \\
\text { 08 August } 2018 \\
\text { Available Online: } \\
\text { 10 September } 2018\end{array}$ \\
\hline
\end{tabular}

\section{Keywords}

education, Moral

values, Ethics

Accepted:

August 2018

10 September 2018

\section{A B S T R A C T}

Ethics has been derived from Greek word 'ethos' means character, is an inherent feature of a civilized society. It is a mental yardstick which focuses the mind to distinguish between good or bad behavior, character and practices running around our society, country or world. Value is a term used in economical and philosophical context where economy pertain its price value among the commodity, while philosophy deals its useful contribution for mankind. The smallest unit of society is home, a place where learning of human values, moral duties and ethical values are nurtured by elders to younger's since ages. The present system of primary and higher education is not solely responsible for decline of ethics and values. Globalization is also a root cause for the decline because people become materialistic rather than moral. Higher education also focuses on skill development part rather than humanity part of students just to make their names on global standards. The main aim of imparting moral values and ethics during Gurukul system was to build a positive character among students that lead to make a true citizen and ultimately leads to gear up nation building process. Around the globe the declining trend of value and ethics is a burgeoning problem which needs to tackled soon. With the advent of modern technology from British rule skill education was emphasized rather than value education. Our vedic education tenets like dharma, artha, kama, moksha were forgotten from the modern education. In the present day corporate culture teaches only the mannerism part but the truthful inceptions of ethical values are still absent there. In a mechanized world where electronic gazettes are present viz. television, computers, radio and $4 \mathrm{G}$ internet services provide every information either good or bad in decent form. Social networking sites face book, twitter and instagram also makes our relationship closer but also ruined the emotional wall between elders and youngers on the name of frankness, which is a grave concern for ethical and moral values. In this paper we will discuss about the causes and possible solution regarding the improvement in ethical values and the role of education system to inculcate ethical values into the students by modifying the curriculum of schools and colleges. 


\section{Introduction}

The literal meaning of Decline is losing anything in a gradual manner. Than a question comes that whether the true gentlemen or humane characters like Moral values and ethics still exist in this world? First we deal the terms ethics, morality, education, philosophy deal the term Ethics with the morality. The word ethics has been derived from the Greek word "ethos"e which means character (Pabla, 2011). Aristotle concluded ethics was more than a moral, religious or legal concept. To determine what is ethically good for the individual and for the society, he said, it is necessary to possess three virtues of practical wisdom: temperance, courage and justice (Pabla, 2011). Our Indian culture is recognized worldwide unique because it has blossomed values. For example in Hindu's perception there are four primordial embodiments- Dharma, Artha, Kam and Moksha and Five practices- Satya, Ahinsha, Astaya, Aparigrah and Brahmacharya (Gupta Pallavi, 2016). Conclusively termed as human values, Morality and humane Character are the main jewels of good human. Recent crisis in 'values' in our youth has revived concern for value education in India.

\section{Objectives of this study were as follows}

To analyze the need of ethics in human being.

To analyze the need of morality.

To study the need of education.

To study the Salient Features of ancient education system.

To analyze the methodology of ancient Indian Education System

To analyze the Salient features of British education system
To analyze the Features of Present education system

To analyze the Present scenario of education system in India

To analyze the Causes of ethical deterioration in Indian education system

\section{Materials and Methods}

This study was focused to discuss the causes of decline of ethics and moral values in present scenario, by the critical review through the studies of ancient education system, British education system and Present education system and various issues related to higher education. Through the review analysis come suggestive recommendation has given for the upgrading the quality education in India. To discuss the topic various data has been gathered from the various sources viz., various websites of ministry of HRD, UGC different related papers.

\section{Role and challenges of higher education in India}

Education is a total metamorphosis of human being, it's a change in the uncivil behavioral pattern into a civic one, it paves the way towards total constructive behavioral change in a human being, it is not only to gain knowledge to read or write a few alphabets, numerical or few Hindi words.

\section{What is the need of ethics in human being?}

Ethics is a mental yardstick which focuses the mind to distinguish between good or bad behaviour, character and practices running around our society, country or world to save humanity on earth man have to possess ethical values, otherwise man and animals are same, the greediness of human can only be satisfied by attaining the true knowledge (Almond, 
1999). Ethics in education might bring the change in human mind. What kind of ethics we are talking here? According to Rushmore Kidder's research, we are talking about the following ethics in education are (Ethics of justice, Ethics of Critique, Ethics of Care, Ethics of profession).

\section{What is the need of morality?}

Morality Refers to personal or cultural value codes of conduct or social values or a body of standards or principles derived from a code of conduct from a particular Philosophy, Religion or culture, or it can derive from a standard that a person believes should be universal. Morality may also be specifically synonymous with "goodness" or "rightness." Yet even through morals can vary from person to person and culture to culture, many are practically universal, as they result form of basic human emotions. Rushmore Kidder pointed 5 important moral values which are Honesty, Respect for everyone, Responsibility for work, Compassion. These moral values have great importance in human life for living peacefully.

\section{What is the need of education?}

Etymologically the word "Education" is derived from the Latin word educatio ("A breeding, a bringing up, a rearing") in general terms education imparts an individual to get understands the theory and practical but also too think logically to reach or solve any problem.

In philosophical terms education literal meaning is to bring desirable changes in human being, it is not simply imparting knowledge in a particular faculty or subject, but at the same time is also training in logical thinking which helps the coming generations adjust to the ever changing environment. It also means opening the doors of the mind, cleansing the soul and realization of the self (Pabla, 2011). Its main aim is to make human life better not only through economic upliftment of individual but also through social, moral and spiritual strengthening. This will not only improve human life but also realize the "higher truth" i.e. "Tamaso $M a$ Jyotirgamaya" from darkness to light. Thus education is not only a way of earning but it also helps to develop human personality with skills, values, morals and enhancement of different attributes of man. So education is a vital means for the potentialities of a human being to emerge in a positive direction so that a man can live in society with full of dignity (Bordoloi, 2011).

\section{Salient features of ancient education system}

Ancient Education system was a meaningful education system; the idea of education has been very grand, noble and high in ancient India. It aim was "training for completeness of life" and the moulding of character of men and women for the battle of life.

In ancient times in India Gurukula system of education was the only system of education (Gupta Pallavi, 2016). Than education system was very prosperous, value-based, skills oriented and was closely linked to nature and life.

\section{Methodology of ancient Indian education system}

The following methodology was used to deliver the education are as follows:

\section{Complete Brahmacharya}

Student will initiate his Brahmacharya phase through Upanayana. A student will be selfdiscipline and self-controlled. All sort of pleasure will be avoided and he must do all the work given by a Guru. 


\section{Learning of Vedas}

The ancient education system was based on four Vedas viz. Rigveda, samveda, yajurveda and atharveda. Rigveda teaches stages of life like family life, forest life and renunciation. Yajurveda teaches how to perform sacrifices in life. Samaveda is study of music. Atharvaveda is the study of medical sciences. Vedas plays an important role in ancient education system Vedas teach our culture, the meaning of life, how we should live, what is right and what is wrong. Ultimately it is learning of Karma, learning of dedication. Vedas are the roots of Hindu Religion.

\section{Learning phases in Ancient Indian education system}

Every student would undergo three phases (Sravana, Manana, Nidhyaasana) every day. Sravana-Means listen and understand, Manana-Is reflecting the things we listened (Shravana), Nidhyaasana-Complete comprehension by the student of the truth that is taught so that he may live the truth and not merely explain it by words. It is the realization of truth.

\section{Salient features of British education system}

After arrival of British Raj, the aim of education underwent a complete change. The British rulers needed cheap clerks to run this country. So they developed a system of education which could produce people to do clerical jobs for them and nothing more.

They had introduced English medium schools and emphasized more on modern science and mathematics and diminished the role of value education system. Skill development part was lacked on their system because they want to make the Indians as workers rather than masters. The modern Indian clerk's feels more closely towards them and a rift between modern education and ancient education had started.

\section{Features of present education system}

Due to the effect of globalization, modernization, industrialization, urbanization, privatization and the influence of western culture raised many problems and evils in Indian society which starts declining ethical values in Indian education system (Pathania, 2011). This system has statistically increase literacy rate but not helps in creating educated persons in the society and as a result it does not produce ideal citizens in the country. The present main objective of Indian students is to be careerist without consideration of ethical values and national spirit in their life. To achieve the success they are using by hook or crook method which hastens uncontrolled corruption and decrease in ethical values, unlawful activities, inhuman behaviour and immoral consumption, which is slowly breaking the structure of Indian society, nation and the world. It is the crucial time to search major causes of declining moral values in Indian education system.

\section{Present scenario of education system in India}

In India today most of the unsocial activities are being committed by well-educated new generation people. The relationship between teacher and student lack confidence towards each other. Students lack humanitarian attitude towards other persons, family, society and the nation. We have established institutions of excellence, still question of degrading human values in higher education is the most burning problem of the country. The main failure of our education system is to inculcating human values. Every person is responsible for this because instead of inculcating good values we have taught our children wrong values. The children are taught to earn money in any 
manner without thinking morality. Earlier societies even without education had these values and preserved them. The values preached by Mahatma Gandhi and all our old great leaders have destroyed on the sake of casteism and communalism. In India approximate 700-750 universities are operating for providing Higher Education in the field of Engineering, Management, Medical, Humanities, Sports \& other Sciences (Gupta Pallavi, 2016). Those practical embodiments which are given importance in human species and through which human behaviour is directed and controlled are known as human values. In each religion there are some moral rules and the followers of the same ought to follow those rules and responsibilities throughout their lives. In Philosophy "People's Perception towards life is considered as human values." Some other people accept that values are deeply rooted in our heritage and Culture. Any culture is identified by its values only.

\section{Causes of ethical deterioration in Indian education system}

\section{Businessization of educational institutes}

Privatization of educational institutes is a major cause for the declining ethical values in education system. The self-financing private institutions with recognition, which may be termed as commercial private education institutions are the major players (Singh and Purohit, 2011). With the mushrooming of these private institutes in the modern era, the education has acquired the status of a marketable commodity, where educational institutes are the traders and students are the customers (Garg and Kaur, 2012). These institutions started courses on any discipline without basic infrastructure and qualified teaching faculties. They appointed teachers on low salary and of inadequate standards. Low salaried teachers have low morale which hampers their performance on the class. Teachers who indulge in unethical practices are arguably unfit for teaching values such as civic education, moral values, honesty and integrity (Hallak and Poisson, 2005). The mushrooming of private education especially in engineering, medical, dental, nursing and management disciplines created a huge unwaged youth and the professional degrees are made into a commodity and are being sold (Singh and Purohit, 2011). Presently thousands of unskilled, untrained and unpaid professionals are produced every year (Garg and Kaur, 2012). This kind of ethical deterioration not only has economic impact but it also has a severe social impact on society.

\section{Lacking of value education in course curriculum}

In ancient India the roots of value and ethics are, the Vedas, the Upanishads and the epics, which upheld the values of Indian society. Imparting value education was the main aim of the Gurus of the ancient age (Pathania, 2011). Today people mostly live in nuclear families and parents are involved in their jobs and they cannot sprout values at home. At present value education is not started at home nor taught at schools in India. Present School curriculum lack emphasize on value education. The present curriculum finds no space to value education, but has the space to make them perfect money makers, politicians, doctors, engineers, artist, actors but fails to inculcate humanity (Harish Bala, 2011).

\section{Corruption in education field}

The major cause of ethical degeneration in education system is rapidly spreading corruption. presently corruption engulfed education system also and it can be defined as " the systematic use of public office for private benefit, whose impact is significant on 
the availability and quality of educational goods and services as a consequence on access, quality or equity in education" (Hallak and Poisson, 2001). Corruption in terms of bribes and illegal fees for admission and examination; academic fraud; withholding teacher salaries; preferential promotion and placement; "tutoring" sessions; textbook procurement, meal provision, transportation, and infrastructure etc.

Present scenario of education system in India

\begin{tabular}{|l|c|}
\hline Total No. of higher institution in India Universities & Total \\
\hline State Universities & 342 \\
\hline Deemed to be Universities & 125 \\
\hline Central Universities & 46 \\
\hline Private Universities & 227 \\
\hline Total & $\mathbf{7 4 0}$ \\
\hline & Source- UGC 2014-15 Report \\
\hline
\end{tabular}

\section{Educator's pedagogy}

The teachers do not have proper teaching methodologies. In the current time novel methods of teaching aids are used to reach the student mind. The Curriculum designed by the university has less relevance to practical knowledge which doesn't create interest among the students. The accumulation or presentation of data is not enough to decide the criteria for quality education.

\section{Student -teacher relationship status}

The teacher itself become selfish for their wealth generation by tuition and coaching and doesn't work for the largest interest of the student. The poor student is unable to get quality education due to lack of money. Hence when a student becomes successful he had not true respect for the teacher. Education becoming a business rather than a mechanism for societal change.

\section{Inadequate Govt. policies}

After independence many commission, committee, policies were setup to improve Indian education system, but the improvement is not satisfactory because the curriculum is based on social and intellectual dimension of education and less weight age is given to values and morals. So the impact of Indian education is not fulfilling its desired needs and aspirations.

\section{Broken marriages}

Everybody wants to be literate, selfdependent but no one is thinking about excellence. Husband and wife both try to dominate there selves and didn't mutually cooperate with each other, which leads to divorce. This situation leads to very bad impact on children's mind. Ego conflicts resulted to broken marriages and nucleus families. The element of human values and moral education is very much needed to achieve the past glory of rich heritage and ethical value of India. School should conduct various value education sessions to meet the rising needs of value education (Sailaja, 2001).

\section{Lack of compulsory faculty training}

Govt. must make an action plan to train all the teaching faculties all over the country irrespective of subjects in the field of ethical and moral values. Because unless and until 
the teacher has the positive attitude towards others, then only the students attitudes will got changed. In the report "Moving towards a Learning society (1995)" on teachers' needs for continuing education has shown that teachers keep up with the times and need continuing education not only for changes resulting from administrative reforms but also in order to upgrade their knowledge of their own subject.

\section{Lack of special training for head of educational institutions}

The role of the principal in creating the working culture and atmosphere of the school is central. In developing the quality of education the head works as an engine to hasten the growth of the institution. Principal should have the competency of manager as well as administrator; therefore, special attention should be paid on the principals' education.

An ethics foundation course, integrating ethics in other subjects across the curriculum, and offering some other initiatives like hosting guest speakers and offering live learning projects, in order to expose students to ethics training.

\section{Lack of teachers and principals evaluation by subordinates}

A feedback cum evaluation report must be filled by the subordinate's officers and an independent authority must handle such confidential work to maintain the transparency of the system. It is just like whistle blower system which means to judge the soft and hard skills of the higher authorities by the lower ones. Now a day's teacher evaluation has started by the students for the teaching skills. Likewise principal's evaluation must be implemented to check their monopolistic approach of work. It will reduce the corruption on lower levels and make a healthy environment among the staff members.

As quoted by Swami Vivekananda education was for "Man Making and Character Building" and Nelson Mandela said "Education is the most powerful weapon which you can use to change the world" The decline of ethical values in education system will give rise to unethical person in all walks of life despite of having a huge success in professional terms. This trend needs to be addressed if India has to survive as a nation and acquire its due place in the world. Corruption, privatization, absence of teacher, undue political interference, inadequate government policies, defective course curriculum, lack of faculty and principal training are the key factors which increases unethical works, are the main causes of ethical decline. The ethical decline also effect the personal and social life of an individual in terms of nucleus family, broken marriages decline of social contacts which leads to create loneliness. The only way to arrest this ethical deterioration is to provide novel modes of value education having the gist of ancient education system. Thus there is an urgent need to re-introduce value based education in the curriculum dealing specifically with human values, to redesign the fabric of Indian educational system with the equal balance of skill and value education. It is matter of research for the social scientist to devise the method to restructure the course curriculum having the jewels of our Vedas and Upanishads.

\section{References}

Almond, B., (1999): Introduction: ethical theory and ethical practice. In B. Almond (Ed.), Introducing Applied Ethics (pp. 1-14). Malden, MAl: Blackwell. 
Bordoloi R., (2011): Challenges in Elementary Education in India: Various Approaches, Journal of Education and Practice, Vol 2, No 7 pp 39-45 www.iiste.org

Garg K., and Kaur K., (2012): Declining of Ethical Standard in Higher Education System in India presented in Cambridge Business \& Economics Conference, Cambridge, UK.

Gupta P., (2016): Degradation of human values in higher education: An analysis" International Journal of Research Granthaalayah, Vol. 4, No. 1 (2016): 165-170.

Hallak, J. and Poisson, M. (2001): "Ethics and Corruption in Education." Paris: IIEPUNESCO.

Hallak, J. and Poisson, M. (2005): Ethics and corruption in education: an overview. Journal of Education for International Development, 1(1) http://equip123.net/ JEID/articles/1/1-3.pdf

Harish Bala (2011): Challenges of Higher Education in 21st Century Journal of
Education and Practice, Vol 2, No 6 pp78-81 www.iiste.org

Pabla M.S. (2011): The Corrosion of Ethics in Higher Education: A Challenge of 21st Century, International journal of management and business studies, Vol. 1(2).

Pathania A., (2011): Teachers role in Quality Enhancement and Value Education, Academe, Vol. 24(1), 19-25.

Sailaja B. (2001): value education in Time of India date Nov 18, 2001.

Singh A. and Purohit B., (2011): Fracas over Privatisation, Quality Assurance and Corruption in Indian higher education, Journal of Education and Practice, Vol 2, No 11\&12 www.iiste.org

Singh A. and Purohit B., (2011): Reconsidering privatisation for corruption free administration in Indian higher education, Education Research Journal, Vol. 1(7): $128-134$ http://www.resjournals.com/ERJ

University Grant Commission: "Higher Education in India: UGC report 201415 " for Universities and Colleges.

\section{How to cite this article:}

Roshan Parihar, Poonam Parihar and Devendra Jeet Sharma. 2018. Decline of Ethics and Moral Values in Present Scenario - An Analysis. Int.J.Curr.Microbiol.App.Sci. 7(09): 1085-1092. doi: https://doi.org/10.20546/ijcmas.2018.709.129 